\title{
Penerapan Brain Gym (Senam Otak) Untuk Meningkatkan Kemampuan Pemahaman Konsep Pajak
}

\author{
Setiawati Wiradinata 1 \\ 1 aisetiawati1962@gmail.com \\ 1 Universitas Islam Nusantara
}

\begin{tabular}{ccc} 
Submitted & Revised & Accepted \\
November 15, 2018 & June 24, 2019 & June 25, 2019 \\
& http://dx.doi.org/10.17509/jpis.v28i1.13913 & \\
\hline
\end{tabular}

\begin{abstract}
Learning Quality Required Lessons from the Period of Time This is supported by students' test score data which more than $50 \%$ of students have not completed their studies. The purpose of this study was to study whether teaching with gym brain movements can improve social studies learning outcomes in the concept of tax. The method in this study is data collection through pre-test and post-test and observation of the learning process in the classroom. The results of this study concluded from which brain training can improve the understanding of the concept of tax, marked by an increase in pretest results in Action I averaging 0.57, increasing in Action II to 4.03, while in Action III increasing again to 6, 30. Similarly, the post-test results increased from the second step from an average of 6.71 (71\%), increasing to 8.74 (81\%), then increasing to 9.03 (97\%).
\end{abstract}

Keywords: social studies learning outcomes, brain gym

\begin{abstract}
ABSTRAK
Kualitas pembelajaran memerlukan upaya inovatif dari waktu ke waktu sesuai dengan perkembangan ilmu dan teknologi. Hal ini didukung dengan data nilai ulangan siswa yang lebih dari 50\% siswa belum tuntas dalam belajarnya. Tujuan penelitian ini adalah untuk mengetahui apakah mengajar dengan menerapkan gerakan brain gym dapat meningkatkan hasil belajar IPS konsep pajak. Metode dalam penelitian ini adalah mengumpulkan data melalui pre-test dan post-test dan observasi terhadap proses pembelajaran di kelas. Hasil dari penelitian ini disimpulkan bahwa penerapan brain gym dapat meningkatkan pemahaman konsep pajak, ditandai dengan peningkatan hasil pre-test pada Tindakan I ratarata 0,57, meningkat pada Tindakan II menjadi 4,03, sedangkan pada Tindakan III meningkat lagi menjadi 6,30. Demikian pula hasil post-test ada peningkatan dari ketiga tindakan yakni dari rata-rata 6,71 (71\%), meningkat menjadi 8,74 (81\%), kemudian meningkat pula menjadi 9,03 (97\%).
\end{abstract}

Keywords: hasil belajar IPS, brain gym

\section{PENDAHULUAN}

Ilmu Pengetahuan Sosial (IPS) merupakan salah satu komponen dari serangkaian mata pelajaran yang mempunyai peranan penting bagi kehidupan nyata di masyarakat. IPS sangat diperlukan agar peserta didik memiliki kepekaan menghadapi gejala- 
gejala dan masalah-masalah sosial yang berakar pada perbedaan suku, ras, agama, dan tata nilai yang terjadi pada lingkungan masyarakat. IPS sebagai salah satu ilmu dasar dewasa ini telah berkembang secara pesat, baik materi maupun kegunaannya. Berdasarkan dari anggapan masyarakat, khususnya di kalangan pelajar, IPS merupakan mata pelajaran sulit dipahami, karena materi terlalu banyak bahkan tidak difavoritkan oleh sebagian besar pelajar.

$$
\text { Kenyataan di lapangan }
$$

menegaskan banyak pelajar yang masih kesulitan dalam menyerap dan memahami pelajaran, khususnya pelajaran IPS, hal itu bisa dilihat dari nilai siswa yang rata-rata masih di bawah KKM. Salah satu penyebabnya adalah siswa masih kesulitan untuk memahami konsep pelajaran yang disampaikan, sehingga materi tidak diserap dengan baik. Hal ini dikarenakan ada faktor internal dan faktor eksternal yang menghambat siswa dalam pemahaman konsep pembelajaran. Kesulitan belajar tersebut jika terus dibiarkan akan sangat berdampak buruk bagi siswa, sehingga siswa sulit untuk meraih prestasi yang diharapkan.

Berdasarkan permasalahan di atas, penulis melaksanakan pembelajaran untuk mengoptimalkan fungsi otak kanan dan otak kiri agar bekerja maksimal dengan penerapan gerakan brain gym, dan penggunaan model pembelajaran kooperatif tipe STAD.

Peserta didik dapat berhasil belajar diperlukan persyaratan tertentu antara lain [1]: menimbulkan minat yang tinggi terhadap mata pelajaran (interest inventory), bakat dan minat yang khusus para siswa dapat dikembangkan sesuai potensinya (differential aptitude test).

Modalitas belajar dapat dilakukan dengan cara-cara sebagai berikut [1]: Menggunakan otak dengan maksimal yang meliputi: (1) Otak kanan berhubungan dengan hati (tersembunyi di bawah sadar), bertugas untuk memunculkan kreativitas, imajinasi, emosi. Penggunaan otak kanan lebih dominan hingga mencapai 80\%; (2) Otak kiri berhubungan dengan pikiran (terlihat di permukaan). Tugas otak kiri berkenaan dengan menganalisis, logika, berhitung, dan meneliti. Untuk penggunaannya hanya mencapai $20 \%$.

$$
\text { Harapan penulis dengan }
$$

penerapan gerakan brain gym, dan penggunaan model pembelajaran yang bervariatif pemahaman siswa terhadap materi ada peningkatan.

Dari pemaparan di atas maka peneliti tertarik untuk melakukan penelitian dengan judul "Penerapan Brain Gym (Senam Otak) untuk Meningkatkan Kemampuan Pemahamam Konsep Pajak Kelas VIII A SMPN 5 Tarogong Kidul."

Berdasarkan latar belakang masalah yang telah diuraikan, maka rumusan masalah dalam penelitian ini adalah sebagai berikut: (1) Apakah penerapan brain gym dapat meningkatkan kemampuan pemahaman konsep pajak pada mata pelajaran IPS di kelas VIII A SMPN 5 Tarogong Kidul? (2) Bagaimana peningkatan kemampuan pemahaman konsep pajak siswa dengan penerapan brain gym di kelas VIII A SMPN 5 Tarogong Kidul?

\section{LANDASAN TEORI}

\section{Brain Gym}

Brain Gym adalah latihan gerak tubuh, yang melibatkan beberapa titik penting yang berkaitan langsung dengan saraf-saraf otak, berfungsi untuk memudahkan pernapasan, memperlancar peredaran darah, menyegarkan dan melemaskan otak. 
Dilakukan untuk memudahkan dan membantu kegiatan belajar, hambatan berpikir, mengurangi stress [2].

Sebelum siswa memulai belajar, mereka harus menjalani PACE. PACE merupakan singkatan dari positif, aktif, clear (jelas), dan energetis. Agar PACE ini berjalan, siswa harus memulainya dari energetis (minum air), clear (melakukan pijat saklar otak), aktif (melakukan gerakan silang), positif (melakukan hook ups) dan dilanjutkan dengan gerakangerakan senam yang lainnya. Untuk penelitian ini langkah-langkahnya hanya dua langkah yakni energetis (minum air) dan aktif (melakukan gerakan silang).

\section{Kemampuan Pemahaman Konsep}

Dalam proses pembelajaran IPS, pemahaman konsep merupakan bagian yang sangat penting dan mendasar. Ini sesuai dengan Taksonomi Bloom yang menempatkan aspek pemahaman pada tahap kedua setelah pengetahuan. kemampuan mengerti pada tahap ini misalnya mampu mengubah informasi ke dalam bentuk paralel yang lebih bermakna [3].

Pemahaman merupakan terjemahan dari istilah understanding yang diartikan sebagai penyerapan arti suatu materi yang dipelajari. Pemahaman berasal dari kata paham, yang berarti menguasai, mengerti, memahami [4]. Sedangkan konsep merupakan buah pemikiran seseorang atau sekelompok orang yang dinyatakan dalam definisi sehingga melahirkan produk pengetahuan meliputi prinsip, hukum, dan teori" [5]. "konsep sebagai suatu abstraksi yang menggambarkan ciri-ciri umum dari sekelompok objek, proses atau fenomena lainnya, dimana dengan ciriciri tersebut, objek, proses, dan fenomena dapat dibedakan," atau secara singkatnya, konsep berarti suatu rancangan [6].
Jadi pemahaman konsep adalah suatu pengertian yang benar dan tepat tentang suatu rancangan atau suatu ide abstrak. Tujuan mengajar adalah agar pengetahuan yang disampaikan dapat dipahami peserta didik [7].

Berkaitan dengan jenis belajar, perlu dibedakan antara belajar konsep dengan belajar proses. Belajar konsep lebih menekankan hasil belajar berupa pemahaman faktual dan prinsipil terhadap bahan atau isi pelajaran yang bersifat kognitif. Sedangkan belajar proses atau keterampilan proses lebih ditekankan pada masalah bagaimana bahan pelajaran dipelajari dan diorganisir secara tepat [8].

\section{Konsep Pajak}

Pajak adalah iuran yang harus dibayar oleh wajib pajak (masyarakat) kepada negara (pemerintah) berdasarkan undang undang dan tidak memperoleh balas jasa secara langsung.

Wajib pajak adalah individu atau badan hukum yang menurut Undangundang Perpajakan ditentukan untuk melakukan kewajiban perpajakan.

Retribusi adalah pungutan daerah sebagai pembayaran atas jasa atau pemberian izin tertentu yang khusus disediakan dan/atau diberikan oleh pemerintah daerah untuk kepentingan orang pribadi atau umum.

Ciri-ciri pajak yaitu (1) Pajak merupakan iuran wajib yang bersifat dapat dipaksakan; (2) Pemungutan pajak dilakukan berdasarkan undangundang; (3) Wajib pajak tidak mendapatkan balas jasa secara langsung; dan (4) Pajak digunakan untuk kepentingan umum.

Dasar-dasar dalam pemungutan pajak yaitu (1) UU No. 16 Tahun 2000 tentang Ketentuan Umum dan Tata Cara Perpajakan; (2) UU No. 17 Tahun 2000 tentang Pajak Penghasilan (PPh); (3) UU No. 18 Tahun 2000 tentang Pajak 
Pertambahan Nilai Barang dan Jasa dan Pajak Penjualan atas Barang Mewah (PPN dan PPnBM); (4) UU No. 19 Tahun 2000 tentang Penagihan Pajak dengan Surat Paksa; dan (5) UU No. 20 Tahun 2000 tentang Bea Perolehan Hak atas Tanah dan Bangunan (BPHTB).

$$
\text { Prinsip-prinsip dalam }
$$

pemungutan pajak yaitu (1) Prinsip Keadilan (Equity). Keadilan dalam pemungutan pajak artinya pajak dikenakan secara umum dan sesuai dengan kemampuan wajib pajak atau sebanding dengan tingkat penghasilannya; (2) Prinsip Kepastian (Certainty). Pemungutan pajak harus dilakukan dengan tegas, jelas, dan ada kepastian hukum; (3) Prinsip Kecocokan/Kelayakan (Convience) Pajak yang dipungut hendaknya tidak memberatkan wajib pajak. Artinya pemerintah harus memerhatikan layak atau tidaknya seseorang dikenakan pajak sehingga orang yang dikenai pajak akan senang hati membayar pajak; dan (4) Prinsip Ekonomi (Economy) Pada saat menetapkan dan memungut pajak harus mempertimbangkan biaya pemungutan pajak. Jangan sampai biaya pemungutannya lebih tinggi dari pajak yang dikenakan.

Setiap pajak terdiri atas beberapa unsur, yaitu (1) Subjek Pajak adalah orang pribadi atau badan yang menurut ketentuan peraturan perundang-undangan perpajakan ditentukan untuk melakukan kewajiban perpajakan termasuk pemungut pajak atau pemotong pajak tertentu, misalnya pegawai, pengusaha, dan perusahaan; (2) Objek Pajak adalah sesuatu yang dikenakan pajak, misalnya penghasilan seseorang yang melebihi jumlah tertentu, tanah, bangunan, laba perusahaan, kekayaan, mobil; dan (3) Tarif Pajak adalah ketentuan besar kecilnya pajak yang harus dibayar oleh wajib pajak terhadap objek pajak yang menjadi tanggungannya. Semua jenis pajak mempunyai tarif yang berbedabeda.

Beberapa bentuk tarif pajak yaitu (1) Tarif pajak progresif adalah tarif pemungutan pajak dengan persentase yang semakin meningkat mengikuti pertambahan jumlah pendapatan yang dikenakan pajak; (2) Tarif pajak degresif adalah tarif pemungutan pajak dengan persentase yang semakin kecil dengan semakin besarnya jumlah pendapatan yang dikenakan pajak; (3) Tarif pajak proporsional adalah tarif pemungutan pajak dengan persentase tetap, berapa pun jumlah pendapatan yang digunakan sebagai dasar pengenaan pajak; dan (4) Tarif pajak tetap adalah tarif pemungutan pajak dengan besar yang sama untuk semua jumlah. Dengan demikian, besarnya pajak yang terutang tidak tergantung pada jumlah yang dikenakan pajak.

Pajak dapat dibedakan menjadi beberapa kelompok, yaitu jenis pajak berdasarkan pihak yang memungut, sifat, dan golongan. (1) Pajak berdasarkan pihak yang memungut, terdiri dari (a) Pajak Negara: Pajak negara adalah pajak yang dipungut oleh pemerintah pusat melalui Direktorat Jenderal Pajak dan Kantor Pelayanan Pajak di bawah Departemen Keuangan. Pajak negara digunakan untuk membiayai pengeluaran negara. Contoh pajak negara, yaitu Pajak Penghasilan (PPh), Pajak Pertambahan Nilai (PPN), Pajak Penjualan atas Barang Mewah (PPnBM), Pajak Bumi dan Bangunan (PBB), bea meterai, bea perolehan hak atas tanah dan bangunan, bea cukai, pajak orang asing, serta pajak atas royalti dan dividen; dan (b) Pajak Daerah: Pajak daerah adalah pajak yang pemungutannya dilakukan oleh pemerintah daerah, baik Pemerintah 
Daerah Tingkat I maupun Pemerintah Daerah Tingkat II. Secara umum contoh pajak daerah antara lain pajak kendaraan bermotor dan kendaraan di atas air, bea balik nama kendaraan bermotor dan kendaraan di atas air, pajak hotel, pajak restoran, dan pajak reklame. (2) Pajak berdasarkan sifatnya, terdiri dari (a) Pajak Subjektif: Pajak subjektif yaitu pajak yang pemungutannya berdasarkan diri wajib pajak, misalnya pajak penghasilan (PPh); dan (b) Pajak Objektif: Pajak objektif yaitu pajak yang pemungutannya berdasarkan objek atau tidak memerhatikan keadaan wajib pajak. Contohnya Pajak Pertambahan Nilai (PPN), Pajak Penjualan atas Barang Mewah (PPnBM). (3) Pajak berdasarkan golongan, terdiri dari (a) Pajak Langsung: Pajak langsung adalah pajak yang harus ditanggung sendiri oleh wajib pajak dan tidak dapat dilimpahkan kepada orang lain. Contoh pajak langsung yaitu Pajak Penghasilan (PPh), Pajak Bumi dan Bangunan (PBB), dan Pajak Kendaraan Bermotor (PKB); dan (b) Pajak Tidak Langsung: Pajak tidak langsung adalah pajak yang harus dibayar pihak tertentu, tetapi dapat dilimpahkan kepada orang lain. Contoh pajak tidak langsung, yaitu Pajak Penjualan (PPn), Pajak Pertambahan Nilai (PPN), dan bea impor. Akan tetapi beban pajaknya diteruskan kepada konsumen dalam bentuk harga jual yang lebih tinggi. Dengan demikian yang membiayai pajak sebenarnya adalah pemakai atau konsumen.

Pajak yang dipungut dari Wajib Pajak mempunyai beberapa fungsi yaitu (1) Sumber Pendapatan Negara: pajak merupakan sumber utama pendapatan negara. Pajak yang dipungut digunakan pemerintah untuk membiayai pengeluaran negara seperti pengeluaran rutin dan pengeluaran pembangunan; (2) Pengatur Kegiatan Ekonomi: Pajak dapat berfungsi untuk mengatur perekonomian. Sebagai contoh untuk meningkatkan investasi; (3) Pemerataan Pembangunan dan Pendapatan Masyarakat: Penerimaan pajak dari masyarakat yang berpenghasilan tinggi digunakan untuk membangun sarana dan prasarana ekonomi di daerah kurang maju, seperti pembangunan pasar, rumah sakit, sekolah, dan sebagainya; dan (4) Sarana Stabilitas Ekonomi: Pajak dapat berfungsi sebagai stabilitas ekonomi. Misalnya untuk meningkatkan kesempatan kerja, pemerintah menurunkan tarif pajak. Tarif pajak yang rendah memungkinkan masyarakat mengeluarkan uangnya lebih banyak untuk membeli barang.

\section{Model Pembelajaran STAD Tim Siswa Kelompok Prestasi}

Tipe Student Team Achievement Divisions (STAD) terdiri dari 5 komponen, yakni [9]: (1) presentasi kelas; (2) pembentukan tim; (3) kuis; (4) perubahan/perkembangan skor individu; dan (5) pengakuan tim.

Langkah-langkah pembelajaran menggunakan model STAD yaitu (1) Membentuk kelompok yang anggotanya 5-6 orang secara heterogen; (2) Guru menyajikan pelajaran; (3) Guru memberi tugas kepada kelompok untuk dikerjakan oleh anggota-anggota kelompok. Anggotanya yang sudah tahu menjelaskan kepada anggota yang lainnya sampai semua anggota dalam kelompok itu memahami materi tersebut; (4) Memberi evaluasi; dan (5) Kesimpulan. Ada delapan fase model pembelajaran kooperatif tipe STAD, yaitu Fase: (1) Guru presentasi, memberikan materi yang akan dipelajari secara garis besar dan prosedur kegiatan, juga tata cara kerja kelompok; 
(2) Guru membentuk kelompok, berdasarkan kemampuan, jenis kelamin, ras, suku, jumlah antara 3-5 siswa; (3) Siswa bekerja dalam kelompok, siswa belajar bersama, diskusi atau mengerjakan tugas yang diberikan guru sesuai LKS; (4) Scafolding, guru memberikan bimbingan; (5) Validation, guru mengadakan validasi hasil kerja kelompok dan memberikan kesimpulan tugas kelompok; (6) Quizzes, guru mengadakan kuis secara individu, hasi nilai dikumpulkan, dirata-rata dalam kelompok, selisih skor awal (base score) individu dengan skor hasil kuis (skor perkembangan) dengan perhitungan sebagai berikut: (7) Penghargaan kelompok, berdasarkan skor perhitungan yang diperoleh anggota, dirata-rata, hasilnya disesuaikan dengan predikat tim (Tabel 2); (8) Evaluasi yang dilakukan oleh guru.

Tabel 1 Perhitungan Skor Tes dan Nilai Perkembangan

\begin{tabular}{ccc}
\hline No. & \multicolumn{1}{c}{ Skor Tes } & Nilai Perkembangan \\
\hline 1. & 5 hingga 1 poin di bawah skor awal & 5 \\
\hline 2. & Skor awal hingga 4 poin di atasnya & 10 \\
\hline 3. & 5 sampai 8 poin di atasnya & 20 \\
\hline 4. & Lebih dari 9 poin di atas skor awal & 30 \\
\hline
\end{tabular}

Tabel 2 Perolehan Skor dan Penghargaan Tim Tipe Stand

\begin{tabular}{ccc}
\hline No. & Perolehan Skor & Predikat \\
\hline 1. & $15-19$ & Good Team \\
\hline 2. & $20-24$ & Great Team \\
\hline 3. & $25-30$ & Super Team \\
\hline
\end{tabular}

\section{METODE PENELITIAN}

Penelitian ini adalah penelitian tindakan kelas yang terdiri dari dua siklus dan tiap siklus terdiri dari empat tahap, yaitu perencanaan, pelaksanaan tindakan, pengamatan, dan refleksi. Penelitian akan dilanjutkan pada siklus berikutnya jika tindakan yang diberikan belum mencapai indikator yang diharapkan. Lokasi pelaksanaan penelitian ini adalah SMPN 5 Tarogong Kidul. Waktu penelitian ini dilaksanakan selama tiga bulan, mulai bulan April 2014 sampai dengan bulan Juni 2014 di kelas VIII A SMPN 5 Tarogong Kidul. Adapun subjek dari penelitian ini adalah siswa kelas 8A SMPN 5 Tarogong Kidul yang berjumlah 37 orang siswa, yang terdiri dari 22 siswa laki-laki dan 15 siswa perempuan.

\section{HASIL DAN PEMBAHASAN}

Dari hasil penelitian yang diperoleh menunjukkan bahwa penerapan brain gym (senam otak) dapat meningkatkan pemahaman konsep pajak siswa kelas VIII A SMPN 5 Tarogong Kidul. Selain itu, dengan penerapan brain gym, siswa menjadi lebih aktif dalam proses pembelajaran. Aspek seperti perhatian siswa sebelum KBM, kerjasama dalam diskusi kelompok, kesungguhan siswa, ketelitian siswa, dan keberanian siswa bertanya mengalami peningkatan dengan diterapkannya brain gym, meskipun peningkatannya masih belum maksimal. Adapun untuk peningkatan hasil belajar siswa dari Siklus I ke Siklus II dapat dilihat dari tabel rekapitulasi berikut ini. 
Tabel 3 Rekapitulasi Skor Pre-test dan Post-test

\begin{tabular}{|c|c|c|c|c|c|c|c|c|}
\hline \multirow{3}{*}{ Skor } & \multicolumn{4}{|c|}{ Siklus I } & \multicolumn{4}{|c|}{ Siklus II } \\
\hline & \multicolumn{2}{|c|}{ Tindakan I } & \multicolumn{2}{|c|}{ Tindakan II } & \multicolumn{2}{|c|}{ Tindakan I } & \multirow{2}{*}{$\begin{array}{c}\text { Tindakan II } \\
\text { Nilai Ulangan }\end{array}$} & \multirow{2}{*}{ Refleksi } \\
\hline & Pre & Post & Pre & Post & Pre & Post & & \\
\hline $0-3$ & 35 & 6 & 16 & - & 4 & - & 3 & - \\
\hline $3-6$ & - & 10 & 8 & 8 & 14 & 1 & 10 & 15 \\
\hline $6-10$ & - & 19 & 7 & 23 & 15 & 32 & 24 & 22 \\
\hline
\end{tabular}

Berdasarkan Tabel 4 di atas, perolehan hasil pengerjaan pre-test dan post-test dalam bentuk skor pada Tindakan I memperlihatkan hasil yang kurang memuaskan. siswa yang memperoleh nilai pada pre-test lebih dari 0-3 sebanyak 35 orang (18.18\%), Siswa yang memperoleh pada post-test nilai lebih dari 0-3 sebanyak 6 orang (17,14\%), siswa yang memperoleh nilai pada pre-test lebih dari 3-6 sebanyak o orang (0\%), Siswa yang memperoleh pada post-test nilai lebih dari 3-6 sebanyak 10 orang $(29,57 \%)$, siswa yang memperoleh nilai pada pre-test lebih dari 6-10 sebanyak o orang (0\%), Siswa yang memperoleh pada post-test nilai lebih dari 6-10 sebanyak 19 orang (53,29\%).

Berdasarkan Tabel 4 di atas, Siklus II pada Tindakan I jumlah siswa yang hadir 33 orang, sedangkan jumlah siswa yang tidak hadir 4 orang, perolehan hasil pengerjaan pre-test dan post-test dalam bentuk skor pada Tindakan I memperlihatkan peningkatan yang baik. Siswa yang memperoleh nilai pada pre-test lebih dari 0-3 sebanyak 4 orang (12,12\%), Siswa yang memperoleh pada post-test nilai lebih dari 0-3 sebanyak o orang (0\%), siswa yang memperoleh nilai pada pre-test lebih dari 3-6 sebanyak 14 orang (42,42\%), siswa yang memperoleh pada post-test nilai lebih dari 3-6 sebanyak 1 orang (3,03\%), siswa yang memperoleh nilai pada pre-test lebih dari 6-10 sebanyak 15 orang (45,45\%), siswa yang memperoleh pada post-test nilai lebih dari 6-10 sebanyak 32 orang (96,96\%). Berdasarkan Tabel 5 menunjukkan bahwa skor pre-test telah ada peningkatan, Daya serap klasikalnya mencapai 96,96\%, dan hanya 1 orang (3,03\%) siswa yang belum tuntas dalam belajarnya, artinya indikator keberhasilan terhadap pemahaman konsep telah tercapai.

Pada Tindakan II peneliti melakukan ulangan harian dari konsep pajak, dan hasilnya memperoleh nilai rata-rata 7,2. Untuk lebih meyakinkan indikator keberhasilan dari penerapan gerakan brain gym peneliti melihat nilai hasil ulangan akhir semester dengan rata rata 65,2 , juga ada peningkatan dari dari nilai ulangan akhir semester yang rata-ratanya hanya 5,8. Hasil pengamatan respon siswa terhadap penerapan gerakan brain gym.

\section{KESIMPULAN}

Berdasarkan hasil penelitian dan pembahasan, maka dapat disimpulkan sebagai berikut: Model pembelajaran STAD dapat meningkatkan skor pre-test dan post-test siswa, dari Tindakan I sampai pada Tindakan III. Pada Tindakan I skor rata-rata siswa kelas VIII A SMP Negeri 5 Tarogong Kidul yaitu 0,57/6,71. Pada Tindakan II yaitu 4,03/8,74. Pada Tindakan III yaitu 6,30/9,03. Berdasarkan skor rata-rata pre-test dan post-test dari Tindakan I, mengalami 
peningkatan sebesar 6,14, sedangkan rata-rata kelas dari Tindakan II mengalami peningkatan sebesar 4,61 dan Tindakan III mengalami peningkatan sebesar 4,42. Begitu juga dengan daya serap klasikal mengalami peningkatan, pada Tindakan III sebesar 93,03, rata-rata nilai ulangan harian sebesar 7,20, dan rata-rata nilai ulangan kenaikan kelas adalah 6,52.

Penerapan gerakan brain gym dapat meningkatkan keaktifan siswa dalam mengikuti proses pembelajaran mulai dari Tindakan I sampai Tindakan III. Keaktifan siswa terlihat dari aktivitas siswa selama proses pembelajaran berlangsung, dengan melakukan aktivitas perhatian siswa, kerjasama, kesungguhan, ketelitian, dan keberanian untuk bertanya dalam kegiatan pembelajaran dari awal sampai akhir, begitu juga gerakan brain gym diterima dengan positif oleh siswa.

Aktivitas guru dalam menggunakan model STAD, telah berusaha meningkatkan motivasi, dan keaktifan setiap siswa supaya mengikuti pembelajaran dengan baik, dan berusaha meningkatkan hasil belajar siswa, walaupun menurut observer pada Tindakan I dan II masih ada kekurangan, yakni siswa belum terbiasa mengajukan pertanyaan. Namun pada akhirnya guru sudah menunjukkan perbaikan dan berusaha supaya setiap siswa aktif mengikuti proses pembelajaran, serta memberikan bimbingan dan arahan yang adil dan intensif pada setiap siswa yang mengalami kesulitan dalam mengikuti proses pembelajaran.

\section{REKOMENDASI}

Berdasarkan skor hasil pengerjaan pre-test, post-test, dan keaktifan siswa yang mengalami peningkatan dari Tindakan I, ke
Tindakan II, dan akhirnya Tindakan II, dan akhirnya Tindakan III. Maka hendaknya model pembelajaran ini dapat diterapkan di kelas lainnya, tidak hanya di VIII A Sehingga peningkatan pembelajaran dapat terjadi secara menyeluruh.

Bagi guru lain yang mengajar Ilmu Pengetahuan Sosial (IPS), model STAD dan penerapan brain gym bisa dijadikan salah satu model pembelajaran yang dapat digunakan untuk meningkatkan proses dan hasil pembelajaran IPS pada siswa. Berdasarkan skor hasil pengerjaan pretest, post-test dan keaktifan siswa yang mengalami peningkatan dari Tindakan I ke Tindakan III.

Untuk pembelajaran dengan menggunakan siklus belajar, bagi peneliti selanjutnya diusahakan ada dokumentasi rekaman video saat pembelajaran berlangsung sehingga dengan dokumentasi tersebut, kita bisa lebih mengetahui lebih jelas sejauh mana penerapan gerakan brain gym dan model belajar STAD dalam siklus belajar, kelemahan-kelemahan serta tindakantindakan apa yang harus diperbaiki.

\section{DAFTAR PUSTAKA}

[1] Endang Komara, Belajar dan Pembelajaran Interaktif. 2014.

[2] J. Pinontoan, "Pengaruh Latihan Keterampilan Gerakan Dasar Merangsang Fungsi Saraf Otak dan Tingkat Ketelitian Terhadap Kemampuan Menghitung Siswa Kelas V Sekolah Dasar," 2006.

[3] H. E. T. Ruseffendi, Pengantar kepada Membantu Guru Mengembangkan Kompetensinya dalam Pengajaran Matematika untuk Meningkatkan CBSA. 2006.

[4] Kamus Besar Bahasa Indonesia, "Pengertian Pemahaman," Pus. Bhs. Depdiknas, 2008. 
[5] S. Sagala, Konsep dan Makna Pembelajaran. 2003.

[6] M. Ulfah, "Upaya Meningkatkan Pemahaman Konsep Matematika dengan Model Pembelajaran Auditory, Intellectually, dan Repetition Menggunakan Peta Pikiran. Skripsi pada Program Studi Pendidikan Matematika," 2010.
[7] H. Hudoyo, "Pengembangan Kurikulum dan Pembelajaran Matematika," Univ. Negeri Malang, 2003.

[8] Fathurrohman \& Sutikno, Strategi Belajar Mengajar Melalui Penanaman Konsep Umum dan Konsep Islami. 2007.

[9] Yatim Riyanto, Paradima Baru Pembelajaran. 2010. 